\title{
Analysis of Newspaper Framing of the Nigerian Governors' Forum Election Crisis of 2013
}

\section{Dominic O. Anyadike}

\author{
School of General Studies, University of Nigeria, Nsukka; combswag@yahoo.com; anyadike66@gmail.com
}

\author{
Doi:10.5901/mjss.2015.v6n6s1p315
}

\section{Abstract}

\begin{abstract}
The Nigerian Governors' Forum election crisis of 2013 has resulted in the polarization of the Forum into two factions. The Forum which has become a powerful lobby has come to assume a strategic importance in the process of deciding who governs in Nigeria. While researches have addressed several issues in the coverage of the Nigerian Governors' Forum (NGF) election crisis, the focus of the press is in the reportage of the events that transpired during and after the election is not known. Based on framing theory which argues that how the media focus on and report issues is how the issues are understood, the study content-analysed 81 stories from five national dailies. The study was guided by four research questions in a multi-stage sampling technique. The findings suggest that, overall, the newspapers' coverage of the Nigerian Governors' Forum election crisis failed to promote peace building process but encouraged the escalation of the crisis. The study concludes that pessimistic leads, headlines and phrases with negative undertones in newspaper reports tend to heighten crisis, and that the calm situation that prevails amidst prolonged misunderstanding do not in any way translate to peace. It is contradictory that the press which is out to promote the de-escalation of crisis is found to whip up sentiment, provoking further crisis instead.
\end{abstract}

Keywords: Analysis, Newspaper Framing, Nigerian Governors Forum, Election Crisis.

\section{Introduction}

The influence and power of the press in building, unifying or destroying a nation state, particularly a complex multi-cultural and multi-linguistic society such as Nigeria is all possible with its framing (Tejumaiye, 2005). This, perhaps, explains Anyanwu's (2004) and Ohaja's (2005) positions when they say that whatever the audience makes of media information or messages is determined by the way such messages are mediated. Thus, how newspapers present any conflict issues should be a thing of concern to the media in general and newspaper operators in particular. This perhaps explains the importance of newspapers in the reportage of elections and electoral crisis which has over-bearing implication on the governance of any nation.

One of the events that require the attention of research in examining how the press mediated election issues is the Nigeria Governors' Forum (NGF) election crisis of May 24th 2013. Available literature show that in that election, "Chief Rotimi Amaechi, the Governor of Rivers State and the incumbent chair of the forum scored 19 votes to beat his challenger, Jonah Jang, the Governor of Plateau State who got 16 votes" (Vanguard, May 25, 2013). Disagreement on the election result snowballed into crisis which continued to linger.

While researches have addressed several issues in the press coverage of the NGF election of 2013, it is not clear what the focus of the press is in reporting the crisis that emerged during and after the election. Specifically, it is not certain whether the newspapers, in their reportage, promoted peace building process or promoted the escalation of the conflict.

The question that is yet to be answered is, what are the implications of the messages inherent in the newspapers' reports of the Nigerian Governors' Forum election crisis in terms of peace building and conflict escalations? The import of this question is echoed in the assertion by Best (2007) which says that "the media can promote peace if they select to, but the media can also promote conflict if they choose to." The thrust of this research is to investigate how the newspapers portrayed the Nigerian Governors' Forum election crisis of 2013.

\section{Nigerian Governors' Forum Election of May $24^{\text {th }} 2013$ in Context}

The Nigerian Governors' Forum (NGF), fashioned after America's National Governors' Association was established after multi-party conference of all 36 governors in 1999 (The Punch, July 19, 2013). The Forum is open to all the elected governors of the 36 states of Nigeria. The Forum seeks to promote better understanding among Governors and ensure a healthy relationship between states and other tiers of government. It became a powerful lobby and at points in time 
influenced: Obasanjo's second term election; the defeat of Obasanjo's third term bid; the emergence of Goodluck Jonathan, first as interim president under the doctrine of necessity and eventual emergence as president (The Guardian , Tuesday May 28, 2013, ). Thus, the NGF has come to assume a strategic importance in the process of deciding who governs in Nigeria. The crisis assumed national dimension considering the fact that the forum had become a major political pressure group in Nigeria. (The Punch, May 25, 2013).

Over a period of twelve months, the disagreement on the election result continued, and consequently, this led to the emergence of two factions of the Nigerian Governors' Forum, one group led by Jonah Jang with majority of members comprising governors of the Peoples Democratic Party (PDP), the ruling political party and the other group led by Rotimi Amaechi comprising mainly governors of All Progressive Congress (APC) party, the major opposition party.

As the disagreements raged and the conflict escalated amid finger-pointing, the Nigerian newspapers did not only propagate the positions of Amaechi's and Jang's groups, they highlighted the discordant voices on the crisis in their reportage.

In this work, the researcher examines the messages of peace and conflict inherent in the newspapers' reports of the Nigerian Governors' Forum election crisis. In this respect, the work reviewed the themes which the newspapers used to frame peace building. Also, the language choices which portrayed escalation of the conflict as employed by the newspapers were reviewed. This research undertaking will afford newspaper editors and reporters opportunity to appraise themselves with a view to avoiding the escalation of crisis. Newspapers, by drawing on frames can have more powerful and effective message delivery, thereby increasing efficiency and enhancing productivity. Furthermore, the work will serve as resource material to other media researchers in the area of media framing.

\section{Statement of the Problem}

As the crisis over the result of the Nigerian Governors' Forum election raged, the Nigerian newspapers were quick to respond to the controversy by highlighting the discordant voices on the crisis. However, while researches have addressed several issues in the coverage of the Nigerian Governors' Forum election crisis, it is not certain what the focus of the press was in the reportage of the events that transpired during and after the election. Specifically, it is not certain whether the newspapers, in the course of framing the NGF election crisis promoted peace building or encouraged the escalation of the crisis. This is the concern of this study.

\subsection{Objectives of the Study}

The primary objective of the study was to analyze the implications of the newspaper reports of the Nigerian Governors' Forum election crisis of 2013 with a view to ascertaining whether the messages inherent in the reports aimed at peace building or escalation of the crisis. Based on this, the following specific objectives guided the study.

1. To determine the major sources of stories on the Nigerian Governors' Forum election crisis of 2013.

2. To determine whether the Nigerian newspapers promoted peace building in the course of the reportage of the Nigerian Governors' Forum election crisis.

3. To identify the salient indicators of peace journalism manifested in the Nigerian newspapers' reports of the Nigerian Governors' Forum election crisis.

4. To determine specific strategies, if any, advocated by the newspapers for enhancement of peace.

\subsection{Research Questions}

The following research questions were raised based on the objectives of the study:

1. What were the major sources of stories on the Nigerian Governors' Forum election crisis of May 24, 2013?

2. Did the Nigerian newspapers promote peace building process in the course of the reportage of the Nigerian Governors' Forum election crisis?

3. What are the salient indicators of peace journalism manifested in the newspapers' reportage of the Nigerian Governors' Forum election crisis?

4. What specific strategies, if any, were advocated by the newspapers for enhancement of peace?

\section{Literature Review}

Scholars have carried out analysis of the pattern of media coverage of diversity and conflict issues using empirical 
approach. Pate (2012) carried out a study which he titled: "practices and challenges of media performance in conflictprone multi-cultural Nigeria." After considering the studies by Ojo, (2000); Yusuf, (2002); Albert, (2002); Akinfeleye, (2003) and Bello, (2005), Pate (2012 ) summarized the common practices that are often prejudicial to the cause of multicultural and diverse Nigeria. According to him, these patterns include the following among others:

i) Promoting, by selective reporting, prejudicial stereotypes about groups and individuals.

ii) Reporting intergroup conflicts out of their fundamental sociological, economic, political and other contexts ...

iii) The use of inflammatory, misleading and sensational headlines to attract sales.

iv) Publishing rumors as facts.

In their study on media coverage of crisis, Fritz and Methewson (1957) found out that early media reports in the wake of crisis are not only confused but also disorganized and carry conflicting information which contain "gross ambiguities and inaccuracies" (Omenugha and Ukwueze, 2008).

In his work titled: "Reducing crisis through peace journalism: A review of newspaper reports of casualty figures of communal crisis in Plateau," Galadima (2008) argues that national newspapers in Nigeria are very important in the management of crisis in the country. According to him, when conflict occurs pressure mounts on the media not just to disseminate information but also to spread the message of peace and reconciliation. However, and unfortunately too, coverage of conflict tends towards sensationalism (Galadima, 2008). In that circumstance, coverage has tended to ignore the analysis of issues that surround conflict, the motivations and interests of various actors and the way forward in conflict management.

Also, scholars tend to agree that the media have not played their roles satisfactorily during conflicts in Nigeria. According to Okafor (2003), the Nigerian press is polarized along regional, sectional or ethnic lines where every side protects and supports their kith and kin. Arguing further, he says: "In the coverage of elections, there is recklessness and partisanship on the part of the press instead of restraint and responsible reporting of events" (Anaeto and Anaeto, 2008). Oboh (2008 cited in Anaeto and Anaeto, 2008), agrees that some journalists participate in crisis by lending support to the narrow-interest of their political-proprietors. According to him, most of the crisis in Nigeria were avoidable, but for the unguided press reports..

Pate (2007), in his work titled: "Reporting conflict and diversity in the Nigerian media" has argued that the politicisation (poor mediation) of diversity and conflict issues in pluralistic Nigeria has been partly accountable for the negative turn of events (cited in Jibril, 2000 and Omebije, 2012). Most probably, this explains the strategic and sensitive nature of the press as a factor of diffusion of tension, or a variable for escalation of conflict.

In their work titled: "War or peace journalism? Asian newspaper coverage of conflicts," Lee and Maslog (2005) content-analysed 1,338 newspaper stories from five Asian countries involved in regional conflicts: India, Pakistan, The Philippines, Indonesia and Sri Lanka. Using the individual story as the unit of analysis and, based on a frequency count of 5,220 , they found out that the three most salient indicators of war journalism were a focus on the here and now (17.60\%), an elite orientation (15.4\%) and a dichotomy of the good and bad (10.3\%). Lee and Maslog (2005) also found out that the coverage of the four Asian conflicts was dominated by a war journalism frame.

The study by Ojwang (2009) involves the content analysis of the implications of messages of peace and conflict interpreted from the utterances of key political players in the 2007-2008 post election violence in Kenya as reported by the main stream newspapers. Specifically, the analysis examines the language choices that the media used to frame the hopes, fears, expectations and disappointments entailed in the messages (Ojwang, 2009). Using a sample size of 20 issues of The Standard and five issues of Sunday Standard, 13 issues of the Daily Nation and seven of the Sunday Nation in his analysis, he found out that, given the unprecedented post-election violence, the Kenyan press oscillated between peace building and peace threatening modes, depending on the prevailing political and public mood. As argued by Galtung (1998) and cited in Lee and Maslog (2005), peace journalists concentrate on stories that highlight peace initiatives; tone down ethnic and religious differences, prevent further conflict, focus on the structure of society; and promote conflict resolution and reconciliation.

Literature shows that a vital function of the press includes mediation and advocacy for peace. With regard to the Nigerian Governor's Forum election crisis which has had significant implications on the over-all dynamics of governance in Nigeria, no literature has provided insite to how the Nigerian newspapers stood on peace-conflict dichotomy while reporting election crisis in Nigeria. Using the Nigerian Governors' Forum election crisis, this study attempts to provide insite to how newspapers stood on peace- conflict dichotomy while reporting election crisis in Nigeria

\section{Theoretical Framework}

This study is anchored on the theory of framing. 


\subsection{Framing Theory}

In Kim's (2003) view, "framing occurs when journalists select an aspect of perceived reality and make it more important in their news story than other aspects by promoting a particular problem or interpretation." Entman (1993 cited in Kim 2003) was more emphatic when he explained how the media frame an issue or story:

Framing essentially involves selection and salience. To frame is to select some aspects of a perceived reality and make them more salient in a communicating text in such a way as to promote a particular problem definition, casual interpretation, moral evaluation, and/or treatment recommendation for the item described.

This specific way of characterising a news story, according to Oladeinde and Ajibola (2007), can influence the attitudes and behaviours of the audience. It involves the selection of certain facts from a continuous flow of information, emphasizing specific issues or events over others and presenting them in a specific order. "By selecting certain information and highlighting it to the exclusion of other information, framing can shape public opinions and audience interpretations of issues and events." (Resse, Grandy and Grant 2001).

The implication of this assertion is that the effect of the messages is not determined by the differences in the contents but by the differences in the modes of presentation. Scheufele and Tewksbury (2007) put it more succinctly: "it is based on assumption that how an issue is characterised in news reports can have an influence on how it is understood by audiences."

Sufficient evidence abounds to show the effects of framing on audiences. According to lyengar and Simon (1997) cited in McQuail (2008) framing of news has encouraged audiences to endorse military rather than diplomatic solution. In the same vein, McLeod and December (1999) "found that differently framed news report of the same protests had different effects on views."

The issue of framing as it relates to the topic under investigation entails how newspapers select and tell the stories about the Nigeria Governors' Forum election crisis so as to capture the attention of the audience. This understanding implies that whichever way and manner the Nigerian Governors' Forum election crisis is reported in newspapers will reflect how it is understood by audience. It is in this context that Best (2007) argues that "the media can promote peace if it select to, but the media can also promote conflict if it chooses to."

Thus, the study focuses on finding out how newspapers told the stories of the Nigerian Governors' Forum election crisis of May 24, 2013. In this respect, it is arguable to state that the framing of the crisis by newspapers could provide the enabling environment that favours peace building process thereby leading to the resolution of the crisis. On the other hand, the framing of the crisis stories may impede peace process leading to escalation of the crisis.

\section{Methodology}

Content analysis technique was adopted in this work as the research design. The study involved examination of the manifest contents of selected national dailies in Nigeria. Thus, the use of content analysis is appropriate since the research is concerned with the analysis of the messages of peace and conflict inherent in the newspapers' reports of the Nigerian Governors' Forum election crisis of May 24, 2013. The study combined quantitative and qualitative methods.

In this this study, the population comprised all the national dailies published in Nigeria as listed in the website http:/www.4 imn.com/ng/ with a total of 25 dailies. The following dailies were selected: Daily Sun, Leadership, the Guardian, The Nation, and Vanguard.

The second level of the population comprised the total number of editions $(1,825)$ arising from the selected newspapers to be studied. One month before the election proper was chosen as the beginning of the period of study so as to have insight into the public perception of the election as reported in the national dailies.

Thus, the number of editions of the dailies published between April, 2013 and March 2014, a period of one year (12 months) was calculated. This brought the population of the study to 1,825 editions, that is, 365 editions of each of the five newspapers for the twelve months period of study. The sample size of five newspapers constitutes 20 percent of the population of the 25 leading national dailies in Nigeria as shown in 2014 Newspapers Web Ranking (http://www.4imn. com/ng/).

Five newspapers out of the 25 leading national dailies in Nigeria listed in 2014 Newspapers' Web Ranking (http://www.4imn.com/ng/) were selected by random sampling. Baron and Davis (2005) state that most content analyses have not exceeded 10 percent of population used in analysis. In line with that, 20 per cent sample used in this study is representative of the population.

The sample size of the editions for the period of study was 60 , selected from a population of 1,825 editions. According to Wimmer and Dominick (2011), Stempel (1952) drew separate samples of 6, 12, 18, 24 and 48 issues of a 
newspaper and compared the average content of each sample size in a single subject category against the total for the entire year. He found out that each sample size was adequate. Furthermore, increasing the sample beyond 12 issues did not significantly improve the sampling accuracy.

In accordance with the postulation of Stempel (1952), a sample size of 12 editions per newspaper was chosen which gave a total of 60 editions (ie. $12 \times 5$ newspapers). Thus, 30 editions were selected from constructed weeks while 30 editions were selected from continuous weeks as shown in tables 1 and 2 respectively.

\subsection{Sampling Technique}

\subsubsection{Content Analysis}

Multi-stage sampling technique was adopted in this study whereby varying techniques were involved at different stages in the selection process. First, simple random sampling technique was employed, to select five national daily newspapers out of 25 leading circulation newspapers in Nigeria based on 2014 Newspapers Web Ranking (http://www.4imn.com/ng/) these newspapers have advantage of wide readership being characterized by nation-wide circulation. Besides, they have capacity for in-depth analysis of issues with advantage of earning public respect for their editorial judgement (Ekwueme, 2014).

Considering the above attributes which are common to the 25 listed national dailies, a random sampling technique was therefore adopted to select, first, a sample size of five newspapers. The random method involved balloting which gave each newspaper equal chance of being selected. In the process, each of the 25 national dailies was numbered and the numbers written in pieces of papers which were folded and placed in a box. Samples were drawn without replacement. Sampling without replacement involved removal of any newspaper drawn from subsequent selection. The balloting continued till five newspapers were selected.

In order to avoid bias in the selection of specific edition dates for the study, constructed weeks technique (composite weeks) developed by Jones and Carter (1959) and continuous weeks technique were adopted to select the sample editions. In the constructed week technique, the 12 months period of study was stratified into seven subgroups of particular weekdays where all the editions that fell on Mondays were grouped together; those that fell on Tuesday grouped together and so on. Each subgroup constituted a stratum and the actual editions studied were drawn from each of the strata. To get a sampling fraction, the number of editions to be studied (30) was divided by the number of newspapers (5) under study. This yielded six editions. Thus, six edition dates (days) were randomly selected from the constructed weeks and the same dates were studied across the five newspapers in order to make analyses across the papers. This yielded a total of 30 edition dates. Table 1 shows the constructed weeks and the selected editions.

Table 1: Selected Weekdays from Constructed Weeks for the Period of Study, April 2013 to March 2014.

\begin{tabular}{|c|c|c|}
\hline Day & Edition Dates/ Days & Month \\
\hline Monday & 19 & April \\
\hline Tuesday & 28 & May \\
\hline Wednesday & 6 & November \\
\hline Thursday & 14 & November \\
\hline Friday & 25 & May \\
\hline Saturday & 5 & April \\
\hline Sunday & - & \\
\hline
\end{tabular}

\section{Source: Field Work}

For the continuous weeks, the researcher chooses 30 days that cut across the pre-election, the election proper and the post election periods. Therefore, 6 continuous dates/days were allotted to April, May and any other randomly selected month after May 2013, the post election period. November 2013 was selected for that purpose. Two days each were allocated to the five newspapers for each of the three months making it 30 dates in all (i.e. 2 edition dates $\times 5$ newspapers $\times 3$ months $=30$ ). The same dates were studied across the five newspapers. The dates selected are shown in table 2. 
Table 2: Selected Weekdays from Continuous Weeks for the Period of Study, April 2013 to March, 2014

\begin{tabular}{|c|c|}
\hline Edition Dates/Days & Selected Months in the Study Period \\
\hline $2, \quad 3$ & April \\
\hline $30, \quad 31$ & May \\
\hline $10, \quad 11$ & November \\
\hline
\end{tabular}

Source: Field Work

\subsubsection{Method of Data Collection}

The instrument used for data collection in this work was the code sheet

In this content analysis, the process of coding the manifest contents of the newspapers was carried out in two stages. The latent contents were the interpretations given to the implications. This involved selecting units of analysis and coding

In the selection process, any news story that addressed the Nigerian Governors' Forum election crisis of 2013 was regarded as unit of analysis. They were treated and coded under straight news story, editorials, features and letters to the editor. The study investigated the contents of the above mentioned units of analysis with emphasis on their implications on the crisis.

In the coding process, a combination of a priori and emergent coding methods was adopted to establish the categories. Emergent coding involves establishing the categories after examination of the data while in a priori, categories are established before data are collected. Two independent coders were involved in the coding exercise. These were: The researcher and a post graduate student of the Department of Mass Communication, University of Nigeria, Nsukka, who was specifically trained for that purpose. The coders examined every news story page by page, identifying all straight new stories, editorials, features and letters-to-the editor relevant to the Nigerian Governors' Forum election crisis. In order to analyze the selected stories effectively, a measuring instrument, the code sheet (Appendix 1) was designed using the content categories with study cues under each category.

These variables were represented with numbers and figures to ensure accurate and more dependable analysis:

\begin{tabular}{|c|c|c|}
\hline \multirow[t]{6}{*}{ A. } & Newspaper & 01 \\
\hline & Daily Sun & 010 \\
\hline & Leadership & 011 \\
\hline & The Guardian & 012 \\
\hline & The Nation & 013 \\
\hline & Vanguard & 014 \\
\hline \multirow[t]{5}{*}{ B. } & Story Genres & 02 \\
\hline & $\overline{\text { Straight News }}$ & 020 \\
\hline & Editorials & 021 \\
\hline & Features & 022 \\
\hline & Letters to the editor & 023 \\
\hline C. & Number of Stories & 03 \\
\hline \multirow[t]{5}{*}{ D. } & Story Direction & 04 \\
\hline & Favourable & 040 \\
\hline & Common Grounds & 0401 \\
\hline & Non-partisanship & 0402 \\
\hline & Advocacy Stance & 0403 \\
\hline
\end{tabular}

Educating the public and parties 0404

Less inciting, less emotive, more objective language 0405

Unfavourable 041

Differences 0411

Partisanship 0412

Non-advocacy stance $\quad 0413$

Non-education of public and parties 0414

Inciting, emotive, less objective language 0415

Neutral (Not tilting towards de-escalation or escalation) 042 
E. Strategies Advocated by newspapers

Repeat of the NGF election

Neutral Body Intervention

Dialogue

Litigation

Interim management

Abrogation of NGF

Others

F. Sources of Stories

Reporters

News Agencies

Free lancer

Foreign services
05

050

051

052

053

054

055

056

06

060

061

062

063

\subsubsection{Textual Analysis}

Textual analysis, a qualitative technique is an attempt to use sentences, descriptions, pictures or words to classify the content of a story using appropriate and relevant categories.

This work adopted the constant comparative technique of textual analysis. The technique, first articulated by Glaser and Strauss (1967) is a well-known technique used in textual analysis. According to Winner and Dominick (2011), the technique consists of the following steps:

1. Comparative assignment of incidents to categories

2. Elaboration and refinement of categories

3. Searching for relationships and themes among categories into a coherent theoretical structure.

First, indicators or cues guided the selection and classification of specific strategies which were later refined and re-adjusted to fit into appropriate and emerging categories considering their relationship. The strategies are those advocated by the news stories aimed at the peaceful resolution of the crisis.

\subsubsection{Study Cues}

Story Direction: This is the focus which the news story on the NGF election crisis takes. In their work on the four Asian regional conflicts involving India, Pakistan, Sri Lanka, Indonesia and the Philippines, Lee and Maslov (2005) used coding categories for frames based on Galtung's $(1986,1998)$ classification to produce 13 favourable indicators of peace and 13 unfavourable indicators of peace. These included: reactivity, visibility of effects of war, elite orientation and differences. This work adopted and modified Lee and Maslov (2005) framing categories to arrive at five favourable indicators of peace and five unfavourable indicators of peace in the NGF election crisis of 2013. Details of these indicators which were used to elicit information from the text on dominant peace or conflict frames, were based on two themes: approach and use of language as shown in appendix 2, A and B. In the story, direction categories are: favourable and unfavourable indicators.

Favourable Story Indicators: These indicate de-escalation of the NGF election crisis by focusing on: (1) common ground, (2) non-partisanship, (3) advocacy stance, (4) education of the public and parties, (5) less inciting, less emotive and more objective language.

Unfavourable Story Indicators: These are stories that have tendency to generate or prolong the conflict. They focus on:(1)differences,(2)partisanship,(3)non-advocacy stance,(4) non-education of the public and parties,( 5) inciting, emotive and less objective language.

Neutral Story: A story is considered neutral when it does not express any definite stand on the crisis.

\subsubsection{Validity and Reliability of the Instruments of Measurement}

To ensure the face validity of the instrument (code sheet), two senior lecturers in the Department of Mass Communication, University of Nigeria, and Nsukka examined the code sheet and ensured that it addressed variables the study intended to investigate. Furthermore, the code sheet was content-tested. This is the process of subjecting the unit of analysis as well as their attributes to the objectives of the study. The reliability of the instrument, the code sheet, was tested by using the result of a pilot study conducted to establish inter-coder reliability. Holsti's (1969) formula for calculating inter-coder reliability of nominal data in terms of percentage of agreement as cited in Wimmer and Dominick 
(2011) was adopted to calculate the inter-coder reliability as shown in table 3.

$$
\begin{aligned}
& \text { Inter-coder Reliability } \\
& \text { Where }
\end{aligned}
$$

$M=$ Number of coding decisions on which two coders agree

$\mathrm{N}_{1}$ and $\mathrm{N}_{2}=$ Total number of coding decisions by the first and second coder respectively.

A subsample of 10 percent as suggested by Lacy and Riffe (1996) was selected which yielded a subsample of six editions. The two coders coded content categories $02,03,04,05$ and 06 as shown in pages 13 and 14 using the items under each category as the basis of analysis.

Table 3: Calculation of Inter-coder Reliability

\begin{tabular}{|l|c|c|c|c|c|}
\hline Coders & \multicolumn{5}{|c|}{ Categories } \\
\hline & 02 & 03 & 04 & 05 & 06 \\
\hline Coder A & $4,1,2,1$ & 8 & $4,2,2,6,3,5,2,1,0,2$ & $4,3,5,1,2,2$ & $6,3,0,0$ \\
\hline Coder B & $4,1,2,1$ & 8 & $4,2,2,6,3,5,2,1,0,2$ & $3,3,5,1,2,2$ & $6,3,0$, \\
\hline
\end{tabular}

For coder A, total number of coding decisions $=25$

For coder $B$, total number of coding decision $=24$

Number of coding decisions where coder $A$ and coder $B$ agree $=23$

Inter coder reliability $=\frac{2(23)}{(25+24)}=\frac{46}{49}=\underline{0.94(94 \%)}$

The coefficient of inter- coder reliability is .94 which indicates a high inter- coder reliability because "most published content analyses typically report a minimum reliability coefficient of about $90 \%$ or above when using Holsti's formular"(Wimmer and Dominick, 2011).

\subsubsection{Techniques of Data Analyses and Presentation.}

The study raised a total of four research questions. While the quantitative method was used in answering research questions one, two and four, research question three was answered by the qualitative technique. The data collected were converted into figures and later, presented in the form of tables and frequency distribution. These were analyzed using simple percentages. Each time an indicator was indentified, a score of 1 was assigned to it. At the end, scores for indicators were calculated and if the total for conflict de-escalation exceeded the total score for conflict escalation, such story was classified as promoting peace. On the other hand, where the total score for the escalation of conflict exceeded that of conflict de-escalation, the story was classified as promoting the escalation of NGF election crisis. The newspaper stories/headlines studied are listed in appendix 3 while appendix 4 shows samples of stories analyzed. For the qualitative analysis, the constant comparative technique was used in the analysis of the themes that emerged in the coverage.

\section{Data Presentation and Analysis}

The Nigerian Governors' Forum election crisis message frequencies were counted and picked for analyses. Sixty editions of the five selected newspapers were sampled. The data generated provided answers to the research questions as shown in the tables and figures below.

\subsection{Research Question One}

What are the major sources of stories on the Nigeria Governor's Forum election Crisis? Table 4 provides answer to research question one.

Table 4: Data Showing Different Sources of News Stories on Nigerian Governors' Forum Election Crisis.

\begin{tabular}{|l|c|c|c|c|c|c|c|}
\hline Sources & Daily Sun & Leadership & The Guardian & The Nation & Vanguards & Total & Percent \% \\
\hline Reporters & 15 & 11 & 8 & 13 & 16 & 63 & 77.78 \\
\hline News Agencies & 1 & 2 & 0 & 1 & 3 & 7 & 8.64 \\
\hline Free lancer & 2 & 2 & 3 & 2 & 2 & 11 & 13.58 \\
\hline Foreign Service & 0 & 0 & 0 & 0 & 0 & 0 & 0 \\
\hline Total & 18 & 15 & 11 & 16 & 21 & 81 & $100 \%$ \\
\hline
\end{tabular}


An over-whelming majority of 63 or 77.78 percent of the stories were accounted for by reporters as shown in table 4 . Foreign Service accounted for the least with zero percent. Other sources are the news agencies with 7 or 8.64 percent and free lancer with 11 or 13.58 percent.

\subsection{Research Question Two}

Did the Nigerian Newspapers promote peace building in the reportage of the Nigerian Governors' Forum election crisis?

Table 5 provides answer to research question two. As shown in table 5 , the frequency of unfavourable indicators which are pointers to the escalation of the crisis varies from newspaper to newspaper. However, the total which is 47 or 61.04 percent is more than the number of favorable indicators (21 or 27.27 percent) which suggests escalation of the crisis. Also, The Nation accounted for the highest number of unfavorable indicators (17) of peace while the Leadership accounted for the least (4).

Table 5: Data Showing the Frequencies of Favourable, Unfavourable and Neutral Indicators of Peace.

\begin{tabular}{|l|c|c|c|c|c|c|c|}
\hline Indicators(contents) & Daily Sun & Leadership & The Guardian & The Nation & Vanguards & Total & Percent \% \\
\hline Favourable & 4 & 2 & 4 & 4 & 7 & 21 & 27.27 \\
\hline Unfavourable & 13 & 4 & 5 & 17 & 8 & 47 & 61.04 \\
\hline Neutral & 2 & 1 & 3 & 2 & 1 & 9 & 11.69 \\
\hline Total & 19 & 7 & 12 & 23 & 16 & 77 & $100 \%$ \\
\hline
\end{tabular}

\subsection{Research Question Three}

What are the salient indicators of peace journalism manifested in the newspapers' reportage of the Nigerian Governors' Forum election crisis?

A constant comparative technique of textual analysis was adopted to select salient indicators so as to proffer answer to research question 3. Occasionally, the newspaper reports conveyed messages that apparently focused on reconciliation and unity of the forum in particular and the country in general. The target words and phrases manifested in the reports were grouped under the following categories of favorable indicators:(1) advocacy stance (38.30percent), that is, call for reconciliation and reconciliatory meetings, collaborative engagements, dialogue, emphasis on national interest above self; mediation, tolerance and establishing cordial relation, (2) common ground(3.70percent) (3) less inciting, less emotive and less objective language(8.64percent), (4) non-partisanship (20.99percent) and (5) education of the public and parties(23.46percent) (Appendix 1, A and B). However, advocacy stance, education of the public and nonpartisanship stand out as salient indicators.

What could be interpreted as call for peace and reconciliation is implied in the following: "It is high time Nigerians put national interest above self" (Daily Sun, May 28, 2013); "NGF's problem will be resolved soon .... I strongly believe we will resolve it before the end of the year" (Daily Sun, July 3, 2013). The messages suggest that the newspapers played roles not only in peace process, but also in the management of the crisis. What looks like optimistic understanding and pointer to peace could be adduced from this quote: "But I am assuring you that we are working hard to reconcile with one another" (Daily Sun, May 31, 2013).

The above newspaper messages portrayed optimism, indicating that all hope was not lost after all. However, newspaper reports, highlighted messages which portrayed apprehension, betrayal, distrust, threat to peace and above all, pre-meditation. This pessimistic frame dominated the reports. Prior to the NGF election, newspaper reports portrayed well-established indicators signaling chaos and uncertainty in the outcome of the election. As predicted before the election by a reporter, Azikem Emmanuel, in the Vanguard of May 24, 2013; "but whatever, it is almost generally agreed that given the key issue of 2015 and the stakes involved that today's election could end up a deadlock or lead to the emergency of two chairmen of the forum." Such negative portrayal could heighten tension among audiences. The story portrayed the crisis as premeditated implying that the election was programmed to fail. Thus, phrases and headlines which are considered pessimistic dominantly characterised the news stories.

The newspapers variously described the election and the consequent political situation as: internal wrangling, deceit, cheating, and horse-trading, betrayal of trust, politics of hatred and deprivation; desperation, and intimidation. Pessimistic leads, headlines and phrases with negative connotation carry some level of antagonism and bickering, suggesting that the press could whip up sentiment in time of conflict thereby making the achievement of peace a herculean task. This is reflected in the following reports: "Amaechi told his Plateau State colleague to stop impersonating 
him as Chairman of the Nigerian Governors' Forum, and urged him to keep within the bounds of decorum" (Vanguard, June 17, 2013); "Jang in his response dismissed Amaechi's charge as funny" (Vanguard, June 17, 2013).

\subsection{Research Question Four:}

What specific strategies, if any, were advocated by the newspapers for peaceful resolution of the crisis?

In order to proffer answer to research question 4, a quantitative analysis of the news stories on NGF election crisis was carried out. Messages were examined to generate assertions that imply strategies for peaceful resolution of the crisis. The meaning and context of the target words and phrases were analysed to ascertain how they promoted peace building or potentially threatened peace.

Very few strategies were advocated by the newspaper messages. They range from, mild improvement on the relationship among the Governors to extreme measures such as outright cancellation of the election result, litigation and abrogation of the forum.

Table 6 shows the major categories of strategies and their frequencies according to the newspapers. Strategies categorized under, Repeat of election accounted for a frequency of 14 or 25.45 percent; Neutral body intervention, 4 or 7.27 percent; Dialogue, 23 or 41.82 percent; Litigation, 2 or 3.64 percent; Interim management, 3 or 5.45 percent; Abrogation of NGF, 6 or 10.91 percent and Others accounting for 3.5.45 percent.

Data Table Showing Strategies Advocated by Newspaper Reports for Peaceful Resolution of NGF Crisis.

\begin{tabular}{|c|c|c|c|c|c|c|c|c|}
\hline S/No & Strategies Advocated & Daily Sun & Leadership & The Guardian & Nation & Vanguard & Total & $\%$ \\
\hline 1 & Repeat Election & 5 & 2 & 1 & 3 & 3 & 14 & 25.46 \\
\hline 2 & Neutral intervention & 0 & 1 & 0 & 1 & 2 & 4 & 7.27 \\
\hline 3 & Dialogue & 4 & 2 & 3 & 6 & 8 & 23 & 41.82 \\
\hline 4 & Litigation & 0 & 0 & 0 & 1 & 1 & 2 & 3.64 \\
\hline 5 & Interim Management. & 2 & 0 & 1 & 0 & 0 & 3 & 5.45 \\
\hline 6 & Abrogation of NGF & 1 & 0 & 2 & 3 & 0 & 6 & 10.91 \\
\hline 7 & Others & 0 & 0 & 1 & 0 & 2 & 3 & 5.45 \\
\hline & Total & $12(21.825 \%)$ & $5(9.09 \%)$ & $8(14.54 \%)$ & $14(25.45 \%)$ & $16(29.09)$ & 55 & 100 \\
\hline
\end{tabular}

The following messages in the newspaper reports which entail strategies were pointers to the enthronement of reconciliation and peace building. For instance, members of the public advocated thus: "Disband Governors' Forum" (Vanguard, May 28, 2013 ); "NGF Crisis: Let there be dialogue" (The Guardian, May 28, 2013);

The foregoing underscores determined efforts for peace. However, the strategies, though relevant and favourable to peace building did not portray concrete measures that would douse tension and guarantee peace. That is, the messages failed to portray specific actions to harmonize meaningful realisation of peace.

On the other hand, the newspapers portrayal of unending misunderstanding and polarisation of the NGF into two factions implies that the positions of the conflicting groups were irreconcilable. This could raise further public apprehension. This is reflected thus: "The NGF now has two factions led by Rivers State Governor Rotimi Amaechi and Plateau State Governor Jonah Jang" (The Nation, May 28, 2013). The following indicate confirmation of the irreconcilable positions of the two factions: "The bottom line of this intricate scenario is that the NGF is dead" (Daily Sun, May 30, 2013). The frame of unending disagreements implied that all efforts at resolving the crisis yielded little or no positive result.

\section{Discussion of Findings}

In this section, attempts are made to answer the research questions.

\subsection{Major Sources of the Stories}

Majority of the stories on NGF election crisis were sourced from reporters who accounted for 77.78 percent of the sources. However, others are free lancer, 13.58 percent and news agencies, 8.64 percent. 


\subsection{Nigerian Newspapers and Promotion of Peace Building Process.}

The result of the analysis in table 5 shows that the Nigerian newspapers did not promote peace building in the course of the reportage of NGF election crisis. This is evident in 27.27 percent accounted for by favourable indicators of peace process as opposed to 61.04 percent accounted for by unfavorable indicators.

The finding corroborates the findings in Okey and Ekhareafo (2013). In their work titled, "Social media as peoples' power: A textual analysis of the January 2013 Anti Fuel Subsidy," the majority (68.2 percent) of the texts were significantly confrontational language which did not support peace process while 12.5 percent was couched in conciliatory tones and 15.0 percent in biased tone.

\subsection{Salient Indicators of Peace Journalism}

The newspaper reports highlighted target words, terms and phrases that are pointers to the possibility of realization of peace. Salient indicators of peace journalism manifested in the newspapers' reportage of the Nigerian Governors' Forum election crisis were: (1) Advocacy stance, (2) common ground (3) less- inciting, less emotive and more objective language, (4) non-partisanship and (5) education of the public and parties. However, advocacy stance (38.30\%), education of the public (23.46\%) and non-partisanship (20.99\%) stand out as salient indicators of peace journalism.

This finding is in line with the conclusion by Fowler (1991 cited in Ojwang, 2009) that journalists and editors may select and transform the news. Furthermore, the news writer frames ideas and opinions by means of information selection and dissemination to audiences. The reports suggest that the campaign for peace by the newspapers is aimed at influencing the public and the Government into taking actions that could guarantee peace in the NGF. For instance, in one of such calls for peace, Daily Sun wrote: "it is high time Nigerians put national interest above self" (Daily Sun, May $28,2013)$.

\subsection{Specific Strategies Advocated by Newspapers for Peaceful Resolution of the Crisis.}

Specific strategies advocated by the newspapers' reports which portray possibility of peaceful resolution of the crisis are shown in table 6. They are: repeat of election, neutral body intervention, dialogue, and litigation. Others are interim management and abrogation of NGF. However, story focus on dialogue (41.82\%) and repeat of the election (25.46\%) constituted outstanding strategies advocated by the newspapers.

\section{Summary}

This work concerned itself with the assessment of the reportage of the Nigeria Governors' Forum election crisis in five selected newspapers, Daily Sun, Leadership, The Guardian, The Nation and Vanguard. Specifically, the work analysed the implications of the newspaper reports with a view to ascertaining whether the message inherent in the report aimed at peace building or escalation of the crisis. The study sought to explore the positive roles newspapers play not only in directing public understanding over conflicting issues, but also countering prejudices and hostility in order to promote synergy among the Governors thereby enhancing good governance

Though there were gestures of peace, the promotion of peace process by the Nigerian newspapers in the reportage of the crisis was not satisfactory. Besides, the newspapers highlighted messages which portrayed apprehension, betrayals, distrust and threat to peace. The strategies advocated by the newspapers for peaceful resolution of the crisis did not portray concrete measures that would douse tension and guarantee peace.

\section{Conclusion}

Based on the findings of the research, it was possible to arrive at the following conclusions:

Pessimistic leads, headlines and phrases with negative undertones in the newspaper reports which portrayed unending disagreements and polarisation of NGF into two factions tended to heighten crisis, thereby creating impediment to early resolution of the crises. Positions of the two factions of NGF were difficult to reconcile and all efforts at resolving the crisis yielded no positive result. The calm situation that exists amidst prolonged misunderstanding and the subsequent emergence of two factional groups of NGF as portrayed by newspaper reports do not in any way translate to peace though dialogue remains the best option for peaceful reconciliation.

The newspapers made efforts not only to promote advocacy, educate the public on the causes of the crisis, the 
positions of the two factions and the political parties involved in the crisis, but also made efforts to counter misconceptions. Also, the newspapers' reports tried to identify the crisis perspectives. Crisis perspective in this context refers to the standpoints, beliefs, values, and views that the primary parties in conflict, that is, Amaechi's and Jang's groups hold about the crisis. In addition, views of the shadow parties (indirect or secondary parties who are not usually visible but their involvement is by proxy) were portrayed as influential in the escalation of the crisis.

\section{Recommendations}

The following recommendations are made considering the findings in the work:

1. Reporters and editors should refrain from excessive use of leads, headlines, and phrases that connote pessimism in the reportage of crisis. Negative connotations in reports of crisis tend to further aggravate controversy. It is ironical and contradictory that the press which is out to influence the de-escalation of crisis is found to whip up sentiment, provoking further crisis.

2. Constant wave of political crisis in Nigeria demands that editors and reporters should undergo training constantly in order to be equipped with new techniques to handle crisis as they arise. Workshops, conferences and symposia should be organised by newspaper organizations for that purpose.

3. There is need for newspapers to be more specific, direct and definite on strategies which they advocate for peaceful resolution of conflict. The framing of crisis issues should be such that contributes to the manageability of the crisis. The newspapers hyped very much on the election results which not only heightened tension but also excited public debate resulting in the polarization of interest groups and uncertainty in the country's polity.

\section{References}

Agande, B. (2013). NGF Leadership Saga: You are fake chairman, Amaechi taunts Jang. Vanguard, Friday June 28, 2013.

Amodu, T. (2013). NGF chair election: D. G. declares Amaechi winner with 19 votes . Saturday Sun, May 25, 2013, p5.

Amodu, T. (2013). NGF crisis: 20 governors absent as Jang faction opens secretariat. Daily Sun, May 31, p.5

Anaeto, S.G. and Solo-Anaeto, M. (2008). Conflict reporting as instrument of conflict resolution in the Niger Delta Area of Nigeria. In E.M. Mojaye; E. Arhagba; E. Soola and L. Oso. (Eds). Media, dialogue, peace building and reconciliation: Conference Proceedings, Abraka, 6-8 August, pp.483-491.

Azikem, E. and Obateru, T. (2013). NGF showdown:Amaechi takes on Jang. Vanguard,Monday June 17.

Baron, S. and Davis, D. (2006). Mass communication theory: Foundations, ferment and future. Noida, India: Fontana.

Best, S.G. (2007). The methods of conflict resolution and transformation. In S.G. Best (Ed.), Introduction to peace and conflict studies in West Africa. Ibadan: Spectrum Books Limited, pp. 93-115.

Galadima, D.J. (2008). Reducing crisis through peace journalism: A review of newspaper reports of casualty figures of communal crisis in Plateau State. In E.M. Mojaye; E. Arhagba; E. Soola and L. Oso (Eds.), media, dialogue, peace building and reconciliation. Conference Proceedings, Abraka, August 6-8,p.553-562.

Kim, K.O. (2003). It is all about trade: United States press coverage of cigarette export talks and policy. Mass Communication and Society, vol.1, No.6, pp 75-95.

Lee, S.T. and Maslog, A. (2005). War or peace journalism? Asian newspaper coverage of conflicts. International Communication Association, pp. $311-326$.

Mamah, E. (2013). NGF: Amaechi floors Jonathan, thanks governors for re-electing him,, pledges to work with Jonathan. Vanguard, Saturday,May 25, 2013, p.5.

McLeod, D. M. and Detember, B.H. (1999). Framing effects of television news coverage of social protest. Journal of Communication, Vol. 19, No. 3, p.5.

Mcquail, O. (2008). Mass communication theory. London: SAGE Publications Ltd.

Oji, M. (2004). Programming for Peace in the Niger Delta: A Case study of Radio Jeremi (JFM 95:1) Peace Broadcast in Warri. A thesis submitted in complete fulfillment of the requirement for the degree of Master of Science in Mass Communication, University of Lagos.

Oji, M. (2006). Communication and conflict resolution: The peace media initiative. International Journal of Communication, No.5. Pp.119132

Omebije, A.Y. (2012). Coverage of Boko Haram activities by selected Nigerian newspapers: A comparative analysis. Zaria Journal of Communication, vol.1, No.1, pp. 99-118.

Omenugha, K.A and Ukwueze, C. (2008). Enemy within: Media reports of crisis in Nigeria. In E.M. Mojaye, E. Arhagba; E. Soola and L. Oso (Eds.), Media, dialogue, peace building and reconciliation. Conference Proceedings, Abraka, August 6-8, pp. 454 - 459 .

Onyekakeyah, L.(2013). NGF crisis: Let there be dialogue. The Guardian, May Tuesday 28, 2013, p.97

Owens - Ibie, N. (2002). Socio-cultural consideration in conflict reporting in Nigeria. In U. Pate (Ed.), Introduction to conflict reporting in 
Nigeria, Lagos: Frankad Publishers.

Pate, U. (2012). Practices and challenges of media performance in conflict -prone multi-cultural Nigera. In M. Mboho and H. Batta (Eds.), The Companion to communication and development. Uyo: Department of Communication Arts, University of Uyo, pp.5568.

Reese, S.D. (1991). Setting the media's agenda: A power balance perspective. In J. Anderson (ed.), Communication Yearbook 14, Newbury Park, California: Sage, pp. 309 - 340.

Shen, F. (2004). Chronic accessibility and individual cognitions: Examining the effects of message frames in political advertisements. Journal of Communication.

Ukeh, O. (2013). NGF: The victor and the vanquished. Daily Sun, Friday May 31, 2013, p.63.Umoru, H. (2013). Amaechi's NGF meets tomorrow, invites Akpabio, Suswam and others. Vanguard, June 25, 2013, p.9.

Wimmer, R. D. and Dominck, J.R.(2011). Mass media research: An introduction, gth edition. Belmont, California: Wadsworth. 